\title{
YEAST COMMUNITIES IN SANDY SOILS (A BEACH OF V REGION, CHILE) II
}

M.A. TORO S.M. \& E. PIONTELLI L. Cátedra de Micología. Escuela de Medicina Universidad de Valparaíso. Casilla 92 V - Valparaíso, Chile

\section{SUMMARY}

With the purpose of detecting the survival of pathogenic or potentially pathogenic yeasts in the sands of marine recreational beaches, a piece of information of ecological interest and related to public health, we investigated the occurrence of ecological interest and related to public health, we investigated the occurrence of yeasts in the intertidal and dry zones of a beach in Viña del Mar (Caleta Abarca), via a monthly sampling during the period of January through December, 1982.

By using such techniques as the standarized count on plates and Cooke's indicator number, we detected 70 yeast species distributed in 13 genera: Condida, Cryptococcus, Torulopsis, Brettanomyces, Trichosporon, Rhodotorula, Sporobolomyces, Hansemula, Pichia, Saccharomyces, Debaryomyces, Dekke$n$, Rhodosporidium. Most of isolated species have a cosmopolitan distribution and we isolated essentially a stationary and transitory microbiota related to hosts differing in quantity and quality; 22 species were isolated in the dry zone an 18 in the intertidal zone. Therefore, beaches represent a reservoir of potentially pathogenic yeast of great concern for public health.

Our results suggest to us the probable use of species of the genus Candida as one of the indicators of fecal contamination in recreational beaches.

\section{INTRODUCTION}

Occurrence of saprophyte and potentially pathogenic yeast communities in different aquatic or associated habitats has become a subject of great concern considering that these organisms are present in rivers, lakes, open sea, deep waters and related to the flora and fauna of the said environments as well as in coastal areas intended for recreational purposes. In this respect there is available information where it is emphasized the existence of significant genera in human and animal pathology (Phaff, Mrak \& Williams, 1952; Fell \& van Uden,

\section{RESUMEN}

[Comunidades fúngieas levaduriformes en suelos arenosos (una playa de la V Región Chile) II.

Con la finalidad de detectar la sobrevivencia de hongos levaduriformes patógenos o potencialmente patógenos en las arenas de plavas recreacionales marinas, información de interés ecológico y relacionada a salud pública, pesquizamos la existencia de levaduras en la zona intertidal y seca en una playa de Viña del Mar (Caleta Abarca), mediante un muestreo mensual entre los meses de Enero a Diciembre de 1982.

Por técnicas como el recuento estandarizado en placas y el número indicador de Cooke, detectamos 70 especies levadurifomes distribuidas en 13 géneros: Candida, Cryptococcus, Torulopsis, Brettanomyces, Trichosporon, Rhodotoruk, Sporobolomyces, Hansenula, Pichia, Saccharomyces, Debaryomyces, Dekkera, Rhodosporidium. La mayor parte de las especies aisladas son cosmopolitas en su distribución, aislandose básicamente una microbiota residente y transitoria asociada a hospederos que difiere en cantidad y calidad: 22 especies fueron aisladas en zona seca y 18 en la intertidal. Por lo tanto las playas representan un reservorio de levaduras potencialmente patógenas de interés en salud pública.

Nuestros resultados sugieren la utilización de las especies del género Candida como uno de los indicadores de contaminación fecal en playas recreacionales.

1961; Volz et al. 1974; Brisols 1975; Boiron, Agis \& Nguyen, 1983). The fact that these organisms are capable of increasing their development in natural media enriched by organic matter has promoted the posibility of assigning them a new role in their biological activity, namely their use as natural indicators of pollution (Cooke et al. 1960; Ahearn and Meyers, 1968; Simard, 1971; Sherry et al. 1979; Paula et al., 1983).

An ecological and epidemiological study on filamentous fungal communities in intertidal areas, beaches and adyacent waters has been carried out in our country in a preceding article (Piontelli et al, 1984). In this survey we will submit results achieved 
parallel to this first information, by referring to yeast " communities in the same geographical location.

Our objectives are similar to those stated in the first part of this paper, but they point to the search of these single-cell fungi capable of surviving and growing in this so much particular habitat by assessing the role that they may have in the epidemiology of certains mycotic diseases.

\section{MATERIALS AND METHODS}

During the period from January 82 to Decem- ber 82 , forty-four surface samples of sand $(5-10 \mathrm{~cm}$ depth) were taken from the recreational public beach of Caleta Abarca in Viña del Mar. Twenty two samples from the intertidal zone wet (I) and 22 from the dry zone (D) (Piontelli et al., 1984). The beach, about $200-\mathrm{m}$ long, was divided in to 4 sections enclosing both zones ( 4 from Zone $I$ and 4 from Zone D), the four samples were chosen at random and mixed in one pool per zone; total of samples being reduced to two areas of Intertidal (I) and Dry (D) sampling.

This operation was performed twice in a month during the periods previously mentioned. It was only in January and July when a single sampling was taken.

PROCESSING OF SAND SAMPLES: a) Standarized count on plate. b) Indicator Number.

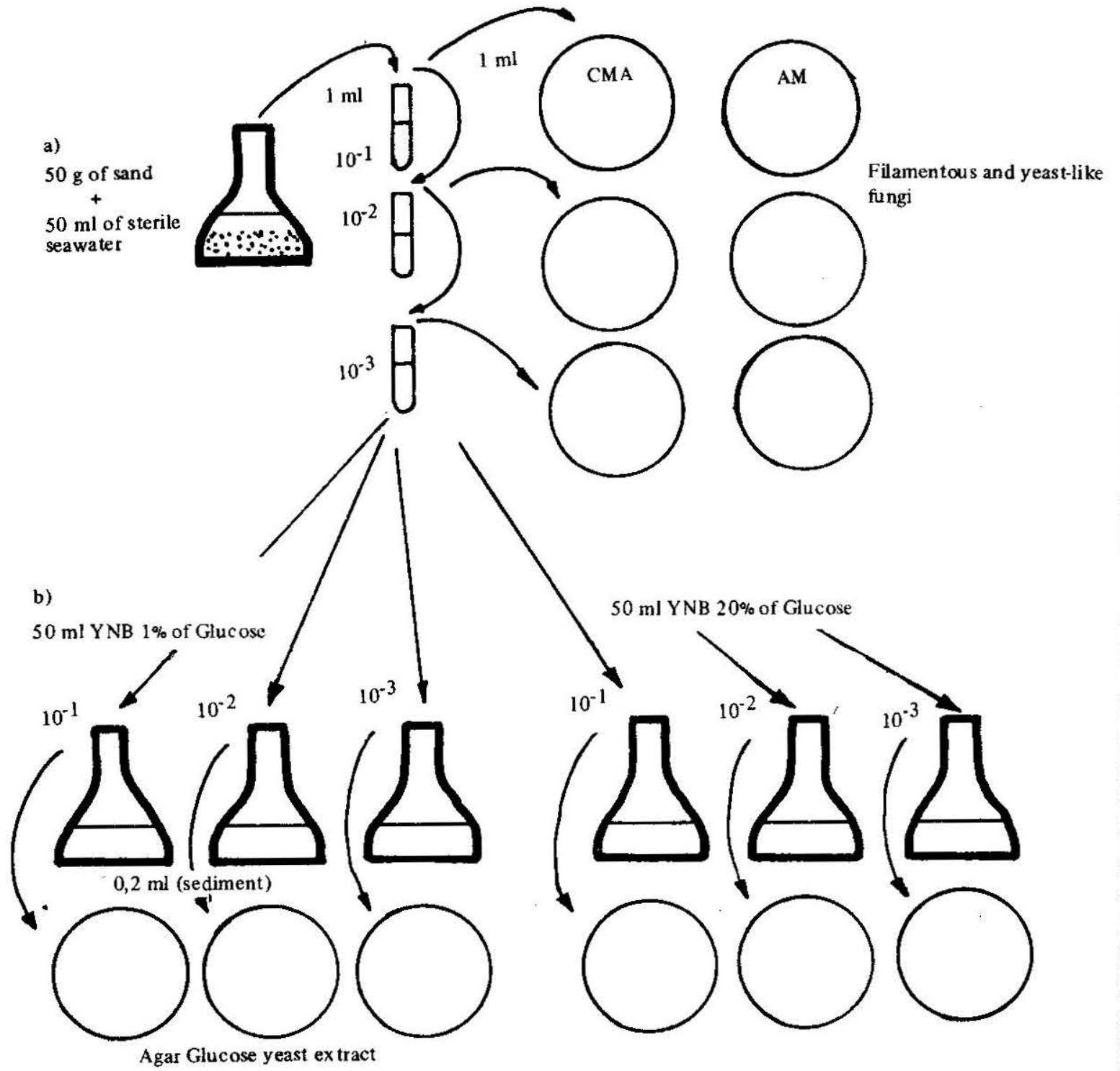

Set of matrasses in shaken at 150 revolution per minute for $64-72$ hours at $25^{\circ} \mathrm{C}$. After a 4-hour settling, seeding is carried out 
The two sampling units were transferred to the laboratory in order to be processed within 24 to $48 \mathrm{hr}$., being stored on ice in the meanwhile.

Samples I and D were divided into equal parts and they were processed by the application of the following techniques with the purpose of isolating the yeast fungi.

A.- Standarized count on dilution plate. (Fred and Waksman, 1928). Part of the sands from zones $I$ and D was used to prepare a base solution with $50 \mathrm{~g}$ of sand in $50 \mathrm{ml}$ of sterile seawater. This sus. pension was shaken for 30 minutes in a mechanical shaker at $150 \mathrm{rpm} .1 \mathrm{ml}$ of this solution was added to a tube containing $9 \mathrm{ml}$ of sterile seawater, after which the first dilution $\left(10^{-1}\right)$ was achieved and so onwards up to $\left(10^{-3}\right)$.

$1 \mathrm{ml}$ of each dilution (I and D) is placed on three $12 \mathrm{~cm}$-diameter petri sterile dishes, adding $18 \mathrm{ml}$ of Com Meal Agar (CMA) with $1 / 000$ yeast extract previously liquified at $45^{\circ} \mathrm{C}$. This same operation is conducted for the Malt agar (AM). All the dishes were incubated at $25^{\circ} \mathrm{C}$ for seven days. Yeast-like colonies are isolated later on AM for their morphological and biochemical study (Lodder, 1970; Bamett et al., 1979).

B.- Indicator Number. (Cooke, 1960). This is a selective technique based on the use of a Yeast Nitrogen Base (YNB) enriched medium that promotes development of yeasts, while on the contrary inhibits that of bacteria.

Twelve matrasses with $50 \mathrm{ml}$ of YNB are prepared, three of them with $1 \%$ of glucose added and to which $1 \mathrm{ml}$ of each dilution of zone $I$ is incorporated; the remaining three are added with $20 \%$ of giucose for the same zone, repeating the spreading of $1 \mathrm{ml}$ from each dilution. This same process is carried out for zone $D$.

This set of matrasses is shaken at $150 \mathrm{rpm}$. in a rotary shaker for $64-72$ hrs. at $25^{\circ} \mathrm{C}$. After 4-hour settling, sediment of each matrass is seeded superficially on $12 \mathrm{~cm}$-diameter plates of agar glucose plus yeast extract. These are incubated at $25^{\circ} \mathrm{C}$ for 7 days. Developed colonies are isolated in AM for their subsequent identification.

\section{RESULTS}

During the period January-December 1982, seventy yeast species were isolated from Caleta Abarca beach in Viña del Mar, 27 from the intertidal zone (I) and 43 from the dry zone (D), encompassing 13 genera: Hansenula, Pichia, Saccharomy ces, Dekkera, Debaryomyces, Rhodosporidium, Candida, Trichosporon, Brettanomyces, Cry ptococcus, Rhodotorula and Sporobolomyces.

A peak can be observed in the number of yeast species isolated in two-month periods of January-February and July-August in zone D. Zone I reveals a similar January-February peak and a practically decreasing behavior until December (Figure 1).

Based on Cooke's modified technique that indicates the number of yeast cells per gram of sand, we can notice some stability in isolations during Summer months, two sudden decreases early in the Winter and the Spring and a marked peak in August in zone $D$, which is coincident with what was observed for the number of species (Figure 1). In zone I we can see some stability in data available recorded between June and August (Winter), whereas the rest of the year keeps low, except in January.

Percentages of occurrence in decreasing order detected in each sampling zone were gathered in 7 groups of taxonomically related genera (Figure 2). The number of isolation for each taxon is pointed out monthly in Table 1. Group I represented by the genus Candida and some of their teleomorphs Han-

FIGURE $N^{\circ} 1$

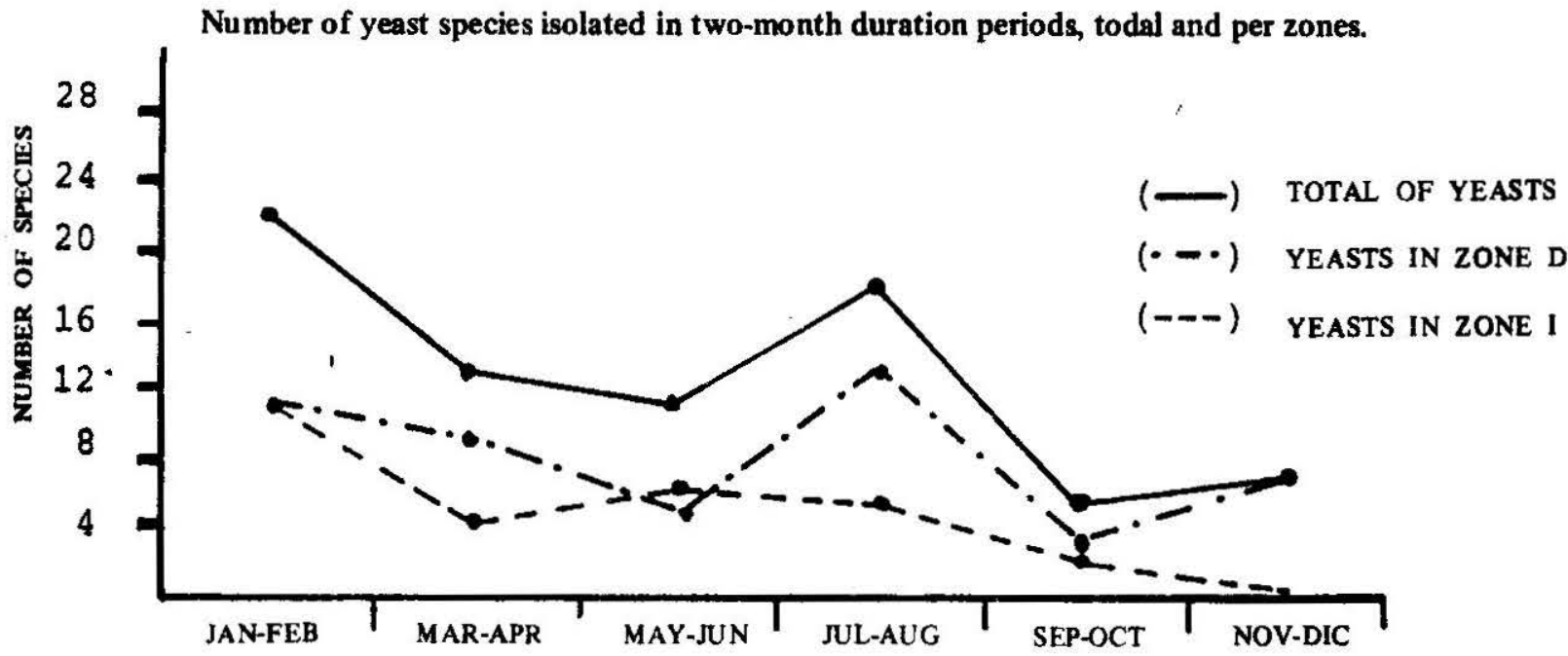


senula, Pichia, Saccharomyœes, reaches the highest percentage $(42,85 \%)$, being detected during every two-month period of the year in zone $D$, the same for group II Rhodotorula and its teleomorph Rhodosporidium with a $25,70 \%$ The five remaining groups exhibit lower percentages of occurrence due to their sporadic character in samples, with the exception of group III wherein the genus Cryptococcus in zone D shows a practically constant presence during every two-month period of the year.

Hansenula anomala in zone D and Candida lusitaniae in zone $\mathrm{I}$ are the yeast species predominating in group I (Table 1).

In group II Rhodotorula rubra stands out, which is present in both zones with the same frequency and in the same period, with the highest recordings of isolates on the yeast total; whereas Rhodosporidium infimo-miniatum comes up only from February to August in zone D.

In group III Cryptococcus laurentii predominates in zone $D$ in the months of Winter and Spring.

In group IV, Debaryomyces hansenii and its anamorph (Torulopsis candida) appear from February to August in zone I from August to December in zone D.

The other isolated species have an intermissive recording both in zone $I$ and $D$ in the different twomonth periods of the year (Table 1).

Occurrence and distribution of species in both zones according to the methodology used allow us to analize this presence under three categories: (a) species detected in both zones during some period of the year, (b) species occurring exclusively in zone $I$ and (c) species which are exclusive of zone D.

a) Rhodotorula rubra and Debaryomyces hansenii predominate in both zones practically all throughout the year and Cryptococcus sp. dominates only in Summer months, whereas Hansenula anomala, Pichia guilliermondii, Rhodotorula glutinis are more constant in zone D and sporadic in zone I. Saccharomyces kluyverii and Candida lusitaniae show a reverse behavior. Candida tropicalis, Pichia polymorpha, Dekkera intermedia and Trichosporon cutaneum were isolated only once in both zones.

b) Candida brumptii, C. membranaefaciens, $C$. mesenterica, Brettanomyces custersianus, Cryptococcus luteolus and Rhodosporidium capitatum are sporadic of zone $\mathrm{I}$.

c) Pichia sp., Candida scottii, Cry ptococcus albidus and Sporobolomyces holsaticus are sporadic and exclusive of zone D. Pichia vini, P. kudrianzevii, Candida parapsilosis and Rhodotula graminis are more frequent, while Cryptococcus laurentii and Rhodosporidium infirmo-miniatum are constant all throughout the year. It is interesting to note the fact that from May-June (Winter), groups III through VII are not detected.

FIGURE No 2

Isolation in a two-month duration period and percentage of presence of yeast genera in each zone of sampling

(I and D)

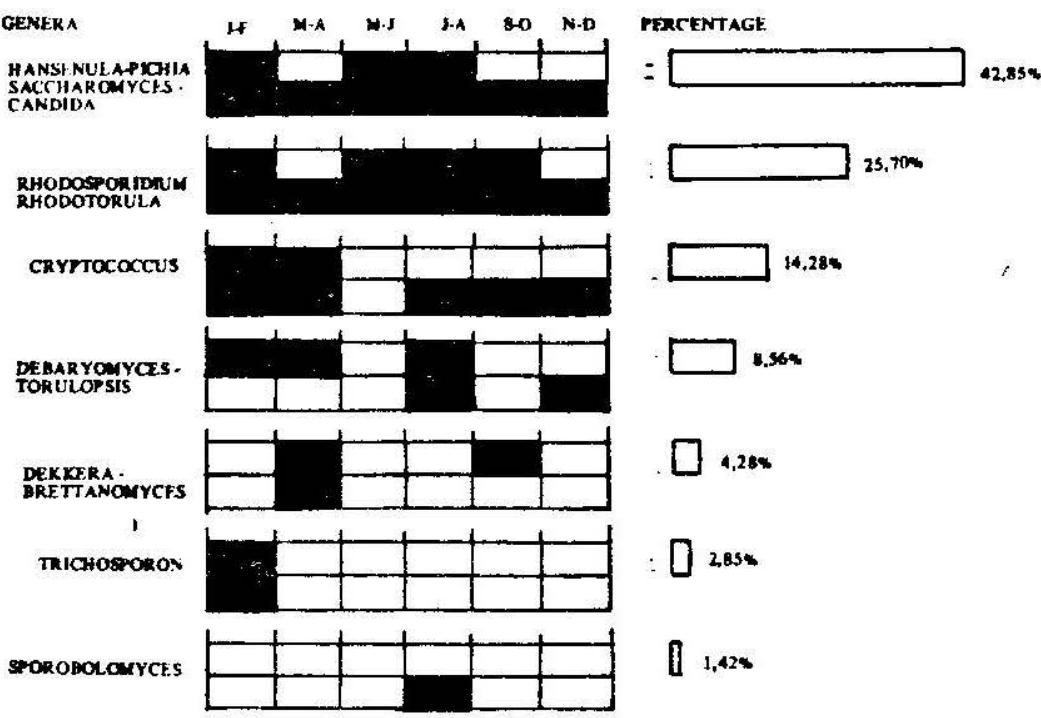


TABLE $\mathrm{N}^{\circ} 1$

Genera and Species isolated per zone and monthly

(*) Hansenula anomala (Hansen) $\mathrm{H}$ et $\mathrm{P}$. Sydow var. anomala

(*) Pichia guillermondii Wickerham

(*) Pichia kudriavzevii Boidin, Pignal et Besson

Pichia polymorpha Klöcker

Pichia vini (Zimmermann) Phaff

Pichia sp.

Saccharomyces kluyveri Phaff, Miller \& Shifrine

(*) (*) Candida brumptii Langeron \& Guerra

(*) Candida lusitaniae van Uden \& Do

$$
\text { Carmo-Sousa }
$$

(*) Candida membranaefaciens Lodder

Kreger van Rij) Wickerham \& Burton

Candida mesenterica (Geiger) Diddens

\& Lodder

Jan.

Jan. Jan. Nov.

Ap. Au. Oc.

Jun.

Feb. Mar. Apr.

$$
\text { Jun. }
$$

Feb. Mar.

Jun.

Feb. Jun.

Feb.

Jan.

Jan. May.

May

(*) Candida parapsilosis (Ashford) Langeron

\& Talice

Candida scottii Diddens \& Lodder

(*) Candida tropicalis (Castellani) Berkhout

Jan.

Jul.

Jul. Aug.

Aug.

Jan. Jul.

30

Rhodosporidium capitatum Fell, Hunter

\& Tallman

Jun.

Rhodosporidium infirmo-miniatum Fell,

苞:

Hunter \& Tallman

Feb. Mar. Apr.

Rhodotorula glutinis (Fres.) Harrison

var. glutinis

Rhodotorula graminis Di Menna

Aug.

Aug. Dec.

Rhodotorula nubra (Demme) Lodder

Jan.Jun.Jul.Oc. Jan.Jun.Jul.Oct.

(*) Cryptococcus albidus (Saito) Skinner var. albidus

Jul.

旁目

Cryptococcus laurentii (Kuff) Skinner

var. laurentii

Cryptococcus luteolus (Saito) Skinner

Jan.

Cryptococcus sp.

Jan. Mar.

Jul.Sep.Nov.Dec.

Debaryomyces hansenii (Zopf) Lodder

\& Kreger van $\mathrm{Rij}$

Feb.Mar.Aug.

Aug.Nov.Dec.

6

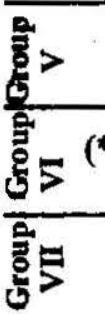

Dekkera intermedia van der Walt

Aug.

Aug.

Brettanomyces custersianus van der Wait

Oct.

(*) Trichosporon cutaneum (De Beurm). Gougerot \& Vaucher) Ota.

Jan.

Jan. 2

Sporobolomyces holsaticus Windisch

Aug.

Note: The asterisks point out the pathogenic or potentially pathogenic yeasts. 


\section{DISCUSSION}

Our results make it possible to detect different behaviors of yeast communities in both zones. Highest isolation of yeast species in zone D reflects also a greater equilibrium of the yeast mycota than zone I, similar to that found in filamentous fungi due to some causes probably identical to those dealt with in part I of our paper.

Yeasts isolated have seemingly three sources of origin: marine, terrestrial and those contributed by human or animal hosts. To establish the borderlines between marine and terrestrial yeasts is still difficult nowadays because of restricted knowledge on physiological and adaptive behavior of yeasts in marine media, wherein the distribution of most taxa is in close relation to distinct environmental factors.

The ability to survive in different habitats is a common characteristic of certain yeasts. Candida parapsilosis, Pichia kudriavzevii, P. guilliermondii, Rhodotorula glutinis var. glutinis, Rh. rubra and Cryptococcus albidus var. albidus, Cryptococcus laurentii var. laurentii and Hansenula anomala var. anomala can be part of the transitory microbiota of man, animals and any other habitat in nature (Stenderup, 1980).

If direct contribution of yeasts coming from the human skin and animals took place, as it can be reasonably thought, during the months with the highest influx of bathers from October to March, there should have resulted a greater isolation of yeasts from the current stationary or transitory microbiota of the latter, but we just could isolate, in a sporadic way, 7 species that satisfy this relationship in nature as commensals, such as Pichia guillermondii, Candida brumptii, C. membranaefaciens, C. tropicalis, Brettanomyces custersianus, Debaryomyces hansenii and Trichosporos cutaneum, all of them sporadic with the exception of Pichia guillermondii and Debaryomyces hansenii which denote a most high frequency. The fact that they fail to accur in the months of Autumn-Winter, in spite of coprophilous contribution of birds and sewage pollution leads us to presume that they are not suitable to grow in the habitat under low temperatures or due to factors of competence.

Boiron et al., (1983) state that the absence of Candida albicans is an indicator of the marine origin oy yeasts collected from beaches. Morris (1968-75), claims that marine yeasts become usually distinguishable in terrestrial habitat and they do not reveal any noticeable metabolic difference (Ahearn et al., 1962; Fell and van Uden, 1963). In our survey we do not isolate Candida albicans considering that we do not make use of selective methods for it (Buck, 1976; Buck and Babucis, 1978). Its limited ability to survive in the absence of a host is suggestive of its not being an autochthonous yeast in natural or polluted waters, its presence in the aquatic environment is merely allochthonous, being contributed by feces from man, animals and birds (Buck,
1977) and conditioned by climatic and ed aphic factors. Seemingly, temperatures lower than that of the host (van Uden and Castello Branco, 1963, van Uden, 1967; Fell and Meyers, 1967; Ahearn, 1973), restrict their survival in this habitat. Temperature recordings taken at sea reached a maximun in the months of December-January $\left(18,60^{\circ} \mathrm{C}\right)$ and a minimum in April-May $\left(13,70^{\circ} \mathrm{C}\right)$. Minimum and maximun recordings in zone I range from 15,5 to $20^{\circ} \mathrm{C}$ and in zone D from 17 to $25^{\circ} \mathrm{C}$, what would suggest that the most suitable zone for yeast growth is zone D, as it can be seen from the greater number of isolates therein while zone I shows conditions comparable to the marine habitat.

Candida albicans has been isolated in recreational beaches (Dabrowa et al., 1964; Kishimoto et al. 1969). Its ability to survive in marine coastal areas or estuarine waters subject to human influence for varying 10-21 day-periods Meyers, 1961; Fell et al., 1963) can be compared to yeasts mentioned above which occurred only during the hot months. This would corroborate the influence of temperature as an advantageous factor for its survival (Buck, 1978). If we analize this situation in the light of marine fecal pollution and hence of adyacent beaches due to the presence of a sewage messenger in the end of our beach under survey and having a knowledge also of the high index of pollution ( $\mathrm{Zahr}, 1983$ ) it is undoubtedly presumed that the greatest contribution of yeasts to beach is of an allochthonous nature.

Spencer et al. (1970), argument that the number of yeasts becomes rapidly increased after the arrival of domestic wastes in the waters, a fact that can be correlated with the increase in total and fecal coliforms (Zahr, 1983), particularly that of pink yeasts (Simard, 1971).

Transfer of yeasts coming from a non saline to a saline habitat seems not to interfere significantly in their development, instead they adapt themselves to the new environmental conditions (Ross and Morris, 1962; Roth et al., 1962; Lee and Baker, 1972), except for some species such as Pichia kudriavzevii which becomes affected by salinity (Johnson and Sparrow, 1961; Grey et al, 1963; Lee and Baker, 1972). In our particular case, this species was only isolated in zone $D$, where salinity is lower $(0,133 / 0$, 191).

Morris, 1968-1975; Queiroz, 1972; Meyers and Ahearn, 1974 and De Paula et al, 1983 postulate that the highest yeast density in coastal waters is contributed by several genera', being most of themCandida, Trichosporon, Cryptococcus, Rhodotorula, Debaryomyces, Pichia, Hansenula and Rhodosporidium, all of which have been isolated in our survey.

Risk represented by these yeast isolates is a kind of problem closely related to Public Health (Brisou, 1975; Buck, 1977) and among the most representative genera of medical concern we can mention species to the genus Candida, Torulopsis, Trichosporon and Cryptococcus.

Pathogenicity of species belonging to the genus Candida has been experimentally shown and 
has been detected as a result of a disturbed condition of the host. It is known that species coming from natural habitats where they live as saprophytes can adapt themselves to parasitic life undergoing among others, some phenotypical changes in their physiology, a growth at $370 \mathrm{C}$, a citric acid ant ethanol assimilation, inhability to ferment maltose and saccharose (Hurley \& Louvois, 1980). These organisms are causal agents of systemic cutaneous and subcutaneous mycoses, being recognised as the commonest among patients who have impaiments of the immune system.

Pichia kudriavzevii, P. guilliermondii, Candida tropicalis, C. parapsilosis, C. brumptii and C. membranaefaciens are included in this group; the first two being the most significant isolates; in hot months, particularly in zone $\mathrm{D}$, they have a varying habitat, human skin and animals, as well as in their feces, intestinal material of fish, industrial residues and different vegetables as well as in marine waters (Lodder, 1971). They are frequently isolated from clinical cases of surface mycoses, Sonck, 1979; Cuci et al., 1983; Soares et al., 1983; López-Martínez et al., 1983; Sebryakov et al., 1984.

Candida tropicalis was isolated in a sporadic way in both zones, just once, Boiron et al. (19821983); Sterre and Agis, 1983 report the same results; it is more restrained to human and animal host, of fecal origin; because of its limited survival its detection is impertant in public health. It is a species related to different pathologies of man such as, aphtha, vaginitis, endophthalmitis, endocarditis, otitis and fungemia (Rose and Kurup, 1977; Tortolli \& Torelli, 1978; Graham 1983; Rao et al., 1984).

Candida parapsilosis of a wide ecological distribution in man and animals; skin digestive tract and feces, alimentary products and soft drinks. Its isolation in Winter months leads us to think of a marine origin caused by fecal contamination. It is likewise recorded in different clinical mycotic cases (Marrie et al., 1984; Mandel et al., 1984; Gilbert and Novak, 1984).

C. lusitaniae is frequent in the digestive tract of domestic animals, being detected in the respiratory secretions and urine of man. As a saprophy te of free life it has been recorded in the coastal waters of Florida, U.S.A. (Lodder, 1971). Its isolation in zone I in the months of January, May and June would be suggestive to us of its coastal origin (fecal contamination)

The genus Cryptococcus becomes another interesting case of adaptability in these sandy soils. It is assumed to be current in non polluted waters; it is, however, rarely recorded in clean waters (Ahearn 1973): De Paula detected in polluted coastal sea water. Our isolation technique do record it from July through December in zone D, C. laurentii var. laurentii and $\mathbf{C}$. al bidus var albidus in July and Cryptococcus sp. in February and March, the latter being the only strain that was isolated in both zones. These species together with $\mathbf{C}$. luteol us are organism having a wide distribution in nature, in soils, water and marine sediments, air, phyllosphere, tree exuda- tions, flowers and fruits; they are connected with invertebrates, insects and mammals. C. albidus var. albidus has been the only one detected in meningitis and mycotic lung infection (Lodder, 1971; Sonck, 1979; Rose and Kurup, 1977). The rest of the species are rarely detected in mycotic cases.

Rhodotorula, as it has been previously stated, is a current genus and of a wide distribution in nature, however, it is being isolated more frequently than ever from mammals. Man is carrier, yet its significance in human pathology is rare. It is sporadically associated to cutaneous and systemic infections (Ahearnet al., 1962; Mok and Silva, 1984).

Rhodotorula rubra, Rh. glutinis var. glutinis, Rhodosporium infirmo-miniatum and Debaryomyces hansenii exhibit both a wide terrestrial and marine distribution (Roth et al., 1962; Meyers et al., 1967; Morris, 1968; Lodder, 1970; Ahearn, 1973; Paula et al., 1983), but some of these are also commensal in man or animals or else they appear as a saprophytic stage on vegetables.

Trichosporon is a genus characterized by its poor adaptability to salinity and to sun exposure (Anderson, 1976). The species T. cutaneum has been isolated from patients suffering from kerato. mycoses besides other filamentous fungi (Genrich, 1962). Nowadys its occurrence as a saprophyte in skin (Badillet and Sené, 1984) is questioned. Its single isolation in January, int both zones, would suggest to us its human and animal origin; it is a strain which has been also detected by Boiron et al., 1983 in Sainte-Anne, in Guadeloupe.

\section{CONCLUSIONS AND COMMENTS}

The survey carried out in Caleta Abarca beach confronted us to the analysis or two classes of ecological communities. The sandy zone D subjected to the action of fluctuating factors such as wind, sunlight, temperature, $\mathrm{pH}$, humidity quantitative and qualitative occurrence of organic and inorganic residues carried by bathers and domestic animals, feces and other excrements of marine birds. Zone I, referred to as intertidal, is characterized by the movement of tides, and wave action and is highly dependent on the aquatic habitat. The real natural habitat of yeast has not been cleanly established yet, though it is possible to postulate that environments represented by flora, fauna and soils make up an ecological situacion more natural than aquatic habitat and adyacent areas applicable to zone I. Ecological studies reveal that most terrestrial entities are capable of adapting themselves to marine habitat and vice versa, what makes them to be undistinguishable. It is logical to conclude that most of isolated taxa are cosmopolitan in their distribution.

We think that species isolated in their teleomorph state result from a selective pressure of environment which would promote their survival in a habitat characterized by the presence of varying 
biotic and abiotic factors, depending on the existence of homothallic strains as it is the case with Debaryomyces hansenii, diploid bisexual state, Hansenula anomala var. anomala or else those of the heterothalic type such as Rhodosporidium infirmo-miniatum and Pichia guilliermondii.

According to reference literature and based on our results confirming dada obtained by these workers in polluted beaches of other latitudes, we agree in recongnising the probable use of species of the genus Candida as indicators of fecal contami- nation in recreational beaches. Methodology applied allowed us to detect essentially a transitory and stationary microbiota associated with hosts differing in quantity and quality; 22 species isolated in zone $\mathrm{D}$ and 18 in zone $\mathrm{I}$.

Taking into account evidence gathered from different investigations and based in isolated species we can conclude that beaches highly concurred and sourrounded with polluted waters represent a reservoir of potentially pathogenic yeast affecting public health (shown by an asterisk in Table 1). 


\section{R E F E R E N C E S}

Anderson J.H. (1979). In vitro survival of human pathogenic fungi in seawater. Sabouraudia $17: 1-12$.

Ahearn, D.G.; Roth Jr., F.J. \& Meyers, S.P. (1962) A comparative study of marine and terrestrial strains of Rhodotorula. Can. J. Microbiol. $8: 121-132$.

Aheam, D.G.; Roth Jr., F.J. \& Meyers, S.P. (1968) Ecology and characterization of yeast from aquatic regions of South Florida. Mar. Biol. (N.Y.) 1 : 291-308.

Badillet, G.; Sené, S. (1984) Is Trichosporon cutaneum only saprophy tic on skin? Bull. de la Soc. Franc. de Mycol. Méd. 13: 163-166.

Barnett, J.A.; Payne, R.W. \& Yarrow, D. (1979) A guide to identifying and classifying yeasts. Cambridge University Press, London, New York, Melboume.

Bergen, L. \& Wagner-Merner, D. (1977) Comparative survey of fungi and potential pathogenic fungi from selected beaches in the Tampa Bay area. My cologia 69:299-308

Boiron, P.; Agis, F. (1982) Etude Préliminaire de la flore levuriforme d'interêt médical. Observêe en millieu marin littoral en Guadeloupe. Bull. de la Soc. de Pathol. Ex. $75: 272-278$.

Boiron, P.; Agis, F.; Nguyen, V. (1983) Etude de la flore levuriforme d'interêt médical de la plage de Saint Anne en Guadeloupe. Bull. de la Soc. de Pathol. Ex. $76: 351-356$.

Brisou, J. (1975) Les levures et les champignons du millieu marin. Bull. Soc. Fr. Mycol. Med 4, (2): 159-162.

Buck, J.D. (1977) Candida albicans, Bacterial Indicators, Health hazards Associated with water, ASTM STP 635. A.W. Hoadley and B.J. Dutka, Eds. American Society for Testing and Materials. pp. 139-147.

Cooke, B.W.; Phaff, H.J.; Miller, M.W.; Shifrine, M. \& Knapp, E.P. (1960) Yeasts in polluted water and sewage. Mycologia $52: 210-220$.

Cooke, B.W. (1965) The enumeration of yeasts populations in a sewage treatment plant. Mycologia 57: 696-703.

Cuci, A.; Nika, B. (1983) Mycological Studies on Candida infection in fetuses of aborting cows. Bul. i Shkencave Zooteknike e Veterinare: $71-80$.

Dabrowa, N.; Landau, J.W.; Newcomer, V.D. \& Plunkett, O.A. (1964) A survey of tide washed coastal areas of Southem California for fungi potentially pathogenic to man. Mycopathol, et Mycol. appl. 24: 137-150.

De Hoog, G.S. (1982) Character Analyses of selected red yeasts. Studies in Mycology No. 22 Centraalbureau voor Schimmel cultures Baarn.
Esterre, P.; Agis, F. (1983) Enquête mycologique sur le sable des plages en Guadeloupe. Bull. de la Soc. Mycol. Med. 12 (1): $115-120$.

Esterre, P.: Boiron, P.: Agis, F. (1983) Bilan des mycoses humanines recontrées en Guadeloupe. Années 1963 à 1982. Revue de la littérature caribéenne. Bul. Soc. Pathol. Ex. 76: 761-765.

Faix, R.G. (1984) Systemic Candida infections in infants in intensive care nurseries: high incidence of central nervous system involvement Journal of Pediatrics. $105: 616-622$.

Fell, J.W.; van Uden, N. (1963) Yeasts in marine environments. In: Oppenheimer, $\mathrm{CH}$. Symposium on Marine Microbiology. Springfield, Charles C. Thomas. pp. 329-340.

Fell, J.W. (1967) Distribution of yeasts in the Indian Ocean. Bull. Mar. Sci. $17: 455-470$.

Gilbert, C.M.; Novak, M.A. (1984) Successful treatment of postoperative Candida endophthalmitis in an eye with an intraocular lens implant. American Joumal of Oph thalmology $97: 593-595$.

Graham, D.R. (1983) Nosocomial Fungemia in a normal host. (Correspondence) Joumal of the American Medical Association 250: 2791.

Hurley, R. \& Louvois, J. (1980) Ecological Aspects of yeast-like fungi of medical importance: Pathogenic potential in the genus Candida. Medical Mycology, Zbl. Bakt. Suppl. $8: 67-72$.

Kishimoto, R.A.; Baker, G.E. (1969) Pathogenic \& potentially pathogenic fungi isolated from beach sands and selected solls of Oahu, Hawaii. Mycologia 61: 537-547

Lodder, J. (1970) The yeasts: A taxonomic study, second edition. Amsterdam North Holland.

López-Martínez, R.; Ruiz-Sánchez, D.; Vértiz-Chávez, E. (1984) Vaginal Candidosis opportunistic factors and clinical correlation in 600 patients. Mycopathol. $85: 167-170$.

Mendel, D.R.; Segal, A.M.; Wysenbeek, A.J.; Calbrese, L.H. (1984) Two unusual strains of Candida arthritis. Américan Journal of Medical Sciences, 288: 25-27.

Marrie, T.J.; Cooper, H.J.; Costerton, J.W. (1984) Ul trastructure of Candida parapsilosis endocarditis. Infection \& Inmunity $45: 390-398$.

Merz, W.G. (1984) Candida lusitaniae: Frequency of recovery, colonization, infection and amphotericin B resistance. Journal of Clinical Microbiology, 20: $10194-1195$ 
Meyers, S.P.: Ahearn, D.G.; Grunkel, W. \& Roth Jr., F.J. (1967) Yeasts from the North Sea. Mar. Biol. (N.Y.) $1: 118123$.

Meyers, S.P.: Ahearn, D.G.; Roth Jr., F.3. (1967) Mycological investigations of the Black Sea. Bull. Mar. Sci. 17 : $579-596$

Mok, W.Y.; Silva, M.S. B. Da. (1984) Mycoflora of the human dernal surfaces. Can. Joum. of Microbiol. $30: 1205-1209$.

Morris, E.O. (1968) Yeasts of manne origin. Oce an ographic Marine Biology, Ann. Rev.. $6: 201.230$.

Morris, E.O. (1975) Yeasts from the natine environment. J. Appl. Bacteriol. $38: 231223$.

Paula, C.R.; Purchio, A.; Gambale. W. (1983) Yeasts from beaches in the southern area of Sio Paulo State "Baixada Santista", Brazil, Rev, Microbiol. São Paulo, $14(2): 136 \ldots 143$

Queiroz, L.A. (1972) Análise quantitativa e qualitativa do leveduras isoladas de águas marinas. 1. Recife. Insituto de Micologia da Universidades Tederai de Pernambuco, publ. 677 .

Rao, G.S.P.: Mann. S.B.S.; Talwar, P.: Arora. M.L. (1984 Primary Mycotic infection of paranasal sinuses. My copa thol. 84: 73-76.

Ruse, W.D.: Kufup, V.P. (1977) Colonization of Hospitalized patients with yeast-like organisms. Sabouraudia $15: 251-256$

Roos. S.S.: Mornis, E.O. (1962) I ffect of sodium chioride on the growth of certain veasts of marine origin J. Sci. Food Agric. 13 (9): $467 \ldots 475$

Roth Jr., F.J.; Ahearn, D.G.; Fell, J.W.: Mryers, S.P.: Mcyers, S.A. (198.2) Fcology and Taxomuny of yeasis isolated from various marine substrates. Limnol. Oceanogr. 7: $178-185$

Sebryakov, E.V.: Parakin, V.P.; Vnronyanskii, V.P. (1984) Candida mycosis in cartle and suine. Veterinariya Moscon :SSR: 4346
Sherry, J.P.: Kuchma, S.R.; Zarzour, J. \& Dutka, B.J. (1979) Occurrence and significance of Candida albicans in Lake Ontario bathing beaches. Scientific Series No. 98 Inland waters directorate, National Water Research institute, Canada Centre for Inland Waters. Burlington, Ontario. Environment Canada.

Simard, R.E. (1971) Yeasts as an indicator of pollution. Marine Pollut. Bull., 2: 123-125.

Soares, E. de C.; Fischman, O.; Baptista, G.; Lobel, L.F. (1983) Mycological and Clinical Studies of 102 cases of nail disorders. Anais Brasileiros de Dermatologia $58: 17 \cdots 20$.

Sonck, C.F. (1979) On the incidence of yeasts species from human sources in Finland. III. Yeast flora of some skin regions (except feets and nails). Mykosen 22 Heft. $4: 129-139$.

Stenderup. A. (1980) Yeast ecology. Fds. Preusser: Medical Mycology, Zbl. Bakt. Suppl. 8: 75 -79.

Spencer, J.F.T.: Goun, J. \& Gadner, N.R. (1970) Yeasts isolated from the south Saskatchewan a polluted river. Can. J. Mierobiol. 16: 1051-1057.

Tortoli. I: \& Torelli, P.C. (1978) Miceti levuliformi isolati da materiali respiratori in ambiente ospedaliero. Ann. Sclavo. $20: 314-318$.

von Arx, J.A.: Rodriguez de Miranda, L.: Smith, M. Th.; Yarrow, D. (1977) The genera of yeasts and the yeast-like fungi. Studies in Mycology No. 14. Centraaibureau voor Schimmelcultures Baarn.

van Uden, $N$ (1967) Occurrence and origin of yeasts in estuarics. In Estuaries (ed. by Lauf., G.H.) pp. 306

Vol2, P.A.; Jerger, D.E.: Wurzburger, A.J.: Hiser, J.L. (1974) A preliminary survey of yeasts isolated from marine habitats at Abaco Islands, The Bahamas. My copath. et Mycol. Appl. 54:313 316.

Zahr, T.M. (1983) Estudio sobre contaminación microbiológica del agua en la bahía de Valparaíso. Memoria para optar al grado de Licenciado en Ciencias con mención en Biología. Universidad Católica de Valparaíso. Facultad de Ciencias Básicas y Matemáticas. Institu to de Biología. 